\title{
The commodification of information and the
} control of expression

\author{
by Fred H. Cate
}

The tendency of legal systems to treat information as property is creating threats to expression, particularly in the areas of copyright and privacy. This article is based on a lecture given by Professor Cate at the Institute of Advanced Legal Studies on 15 May 2002. An earlier version of this article was published as the 2001 Herman B Wells Distinguished Lecture of the Society and the Institute for Advanced Study of Indiana University.

$\mathrm{E}$ xpression is often the target of some form of attack, but most legal systems, reflecting the recognition that threats to expression pose significant risks to societies and to individuals, respond to those attacks with heightened judicial and political scrutiny.

Recently, however, new threats to expression are emerging that are not identified as affecting speech and often, in fact, involve no conscious targeting of expression by a government prosecutor or civil litigant. As industrializèd economies have grown more informationdependent, new laws, and new applications and interpretations of existing laws, increasingly treat information as property or invest individuals with property-like rights in data. Although often motivated by laudable goals, these efforts to create and expand property rights in information pose a significant threat to information flows, and therefore to citizens and consumers.

Unfortunately, there are many examples: expanding the law of trademark to prohibit uses that create no likelihood of consumer confusion; allowing trademark holders to monopolize domain names and to displace others who wish to use those domain names for protest purposes; protecting names, images, voices, and even fictional characters not merely from uncompensated uses but even from open impersonation; extending rights of publicity to last 100 years or more after an individual's death.

Two areas of law, however, have accounted for the most sweeping commodification of information: copyright and privacy.

\section{COPYRIGHT}

In the United States, the Copyright Clause in the Constitution empowers Congress to enact copyright laws to create an incentive for its creation. As the Supreme Court has written, copyright is "the engine of free expression. By establishing a marketplace right to the use of one's expression, copyright supplies the economic incentive to create and disseminate ideas." (Harper \& Row Publishers, Inc. $v$ Nation Enterprises, 471 U.S. 539, 558 (1985).)

The United Kingdom's first copyright law, the Statute of Anne, reflected a similar purpose, as suggested by its title, "An Act for the Encouragement of Learning." By breaking the bookseller's monopoly on disseminating printed expression, the Act created a great demand for new authors and material.

U.S. copyright law goes even further to prohibit the ownership of data. Instead, copyright law protects only expression. In the words of the unanimous Supreme Court: "The most fundamental axiom of copyright law is that ' $[\mathrm{n}] \mathrm{o}$ author may copyright his ideas or the facts he narrates. ...' [C]opyright assures authors the right to their original expression, but encourages others to build freely upon the ideas and information conveyed by a work." (Feist Publications, Inc. v Rural Telephone Services Co., 499 U.S. 340, 344-45, 349 (1991) (quoting Harper \& Row, 471 U.S. at 556).)

Although it may seem unfair that the law does not allow a discoverer of data to own them, "this is not 'some unforeseen byproduct of a statutory scheme," the Court has written. 'It is, rather, 'the essence of copyright,' and a 
constitutional requirement." (Id. at 349 (quoting Harper \& Row, 471 U.S. at 589 (Brennan, J., dissenting)) (citations omitted).)

Recent changes to copyright laws threaten to expand the rights of copyright holders threaten to frustrate those laws' purpose.

\section{Duration}

Nowhere is this clearer than in the length of copyright protection. The duration of copyright in both the United States and the United Kingdom has grown from a 14-year term, which could be renewed by the creator once, to life of the author plus 70 years today.

One might reasonably wonder whether 70 years of posthumous protection creates any additional incentive to create, while it defers for that much longer the moment when a work becomes part of the public domain. Lord Macaulay spoke to this issue in 1841 when Parliament was considering extending the term of British copyright protection to 21 years:

"Now, would the knowledge, that this copyright would exist in 1841, have been a source of gratification to [Dr.]

Johnson? Would it have stimulated his exertions? Would it

have once drawn him out of his bed before noon? . . .

Would it have induced him to give us one more allegory, one more life of a poet. . .? I firmly believe not. . . Show me that the prospect of this boon roused him to any vigorous effort, or sustained his spirits under depressing circumstances, and I am quite willing to pay the price of such an object, heavy as that price is. But what I do complain of is that my circumstances are to be worse, and Johnson's fare none the better, that I am to give five pounds for what to him was not worth a farthing." 56 Parl. Deb. H.C. (3d Ser.) 341, 349-50 (1841) (statement of Thomas Macaulay).

\section{Scope}

Legislatures have also aggressively expanded the scope of copyright. In the United States, to qualify for protection today, a work must be only "fixed"—-that is, captured in some "tangible medium of expression" — and "original" meaning only "independently created by the author (as opposed to copied from other works)." (Feist Publications, 499 U.S. at 345.) No intent to copyright, no notice of copyright, no publication, and no application to the government are necessary. This has expanded exponentially the number of works subject to copyright, and removed that much more expression from the public domain. Copyright law now protects plots, characters, choreography, basketball plays, page numbers, the selection and arrangement of otherwise uncopyrightable facts, sculpture, esthetic shapes, architecture, the "look and feel" of computer programs, voice mail messages, and doodles.

\section{Rights}

Congress and Parliament have also broad created new rights for copyright holders. The U.S. Digital Millennium Copyright Act prohibits the circumvention of technological measures taken by copyright owners to control access to their works-even in those works are not protected by federal copyright law or include facts and ideas which cannot be protected with copyright law. (Pub. L. No. 105-304, 112 Stat. 2860 (1998) (codified as amended at 17 U.S.C. paras. 101 et seq).)

Similarly, the new Act prohibits the removal or alteration of "copyright management information"information conveyed with a copyrighted work that identifies the author or performer and the terms and conditions for the use of the work. Yet it is often impossible or impractical to include the copyright notice when parodying a song, quoting a book, or videotaping a television program for later viewing. While the Supreme Court has ruled that all three of these activities are legitimate uses of copyrighted work, under the defense of "fair use," the failure to include the complete original copyright notice could nevertheless subject the user to statutory fines as great as $\$ 25,000$ per incident, injunctions, damages, costs, and attorney's fees, and even criminal prosecution.

Finally, providers of Internet access must "respond expeditiously to remove, or disable access to, the material that is claimed to be infringing." (Id. para. 512(c)) Think what this means: To avoid liability, a service provider must remove the material stored on its servers by its customers before any adjudication that the material is infringing or that the infringement is not excused by a defense under the copyright law. The law thus creates a tremendous incentive to turn service providers into copyright censors, blocking access to material that may ultimately prove to be wholly lawful.

Europe has gone even further with its directive on the legal protection of databases. The "database right" protects "[a] collection of independent works, data or other materials which (a) are arranged in a systematic or methodical way, and (b) are individually accessible," whether or not by electronic means. (Copyright Designs and Patents Act of 1988 para. 3A (as amended by the Copyright and Rights in Databases Regulation (1997)).) All that is required is that there has been a substantial investment in obtaining, verifying, or presenting the contents of the database, and that the creator be located in the European Economic Area.

The database right prevents the extraction or reutilization of all or a substantial part, or the repeated and systematic extraction or re-utilization of an insubstantial part, of the database. Ironically, "re-utilization" of the contents of a database is defined as "making those contents available to the public by any means"- the very purpose 
that copyright law was intended to serve. The protection lasts for 15 years, but may be extended indefinitely if the contents of the database are substantially revised or updated.

That protection was still further extended by the 2001 British Horseracing Board case, in which the High Court found that William Hill's use of information from the British Horseracing Board's database violated United Kingdom law, even though it was available from other sources, not because the amount taken was quantitatively substantial, but because it was qualitatively important. The Court of Appeal has referred questions from this case to the European Court of Justice, but left the High Court's decision standing. (British Horseracing Board Ltd. and Others v. William Hill Organization Ltd. [2001] EWCA Civ 1268 (31 July 2001).)

By granting ownership rights in actual data-the facts that describe the reality of our existence, facts which may be discovered, but not created - the database right would not only be unconstitutional under U.S. law, but anathema to the historical concept of facts and ideas as part of the common heritage of humankind. Nevertheless, powerful industry lobbies have introduced legislation to create some form of database protection in each of the past five Congresses, so that historical conception is under attack even in the United States.

\section{Contracts}

Finally, contract law is supplanting copyright law as a source of rights for protecting works, particularly in the digital environment. Database providers have long relied on contracts to govern access to, and control reuse of, material contained in their databases. Copyright holders license almost all software, subject to contract terms, rather than sell it outright. And this trend recently gained support in the United States with adoption of the Uniform Computer Information Transactions Act. That Act reflects a concerted effort to use mass market licenses, instead of copyright law, for all transfers of "computer information transactions" - not only software, but "electronically disseminated" news, opinions, pictures, and the like. (Hannibal Travis, "Pirates of the Information Infrastructure: Blackstonian Copyright and the First Amendment," 15 Berkeley Technology Law Journal 777, 840 (2000), and sources cited therein.)

These licenses are used to protect rights that go far beyond those provided by copyright law. They can restrict the use of facts or ideas. They can last indefinitely. They can be used to limit criticism or the development of new and competing materials. They seldom provide for any of the defenses included in copyright law, and they often include penalties and conditions far more severe than those provided by copyright law. Contracts are proving to be an important means for controlling access to information.
Collectively, these changes in copyright law greatly expand the rights of copyright holders and provide them with the legal tools to prevent access to, or use of, the contents of copyrighted works altogether. Legal scholars have described these developments as an "intellectual land-grab" (James Boyle, "A Politics of Intellectual Property: Environmentalism for the Net?," 47 Duke Law Journal 87, 94 (1997).) and a "creeping enclosure of the informational commons." (Peter Jazi \& Martha Woodmansee, The Construction of Authorship 11 (1994).) Unchecked they threaten the public's ability to access and use information.

\section{PRIVACY}

Another area in which information flows are being threatened by new laws and a new focus on property-like rights is that of information privacy.

The past decade has witnessed a surge in legislation, regulation, and litigation designed to protect the privacy of personal information. Although this started in Europe, with adoption of the EU data protection directive, it is catching on in the United States.

The dominant trend in these recent enactments is to invest consumers with near absolute control over information in the marketplace-irrespective of whether the information is, or could be, used to cause harm. Virtually all of the privacy bills pending before Congress reflect this goal: "To strengthen control by consumers" and "to provide greater individual control." (S. 30, 107th Cong. para. 2 (2001); H.R. 89, 107th Cong. para. 2(b)(1) (2001); H.R. 347, 107th Cong. para. 2(b)(1)(A) (2001) (emphasis added)). William Safire summed up this movement towards turning information into property when he wrote in the New York Times: "Your bank account, your health record, your genetic code, your personal and shopping habits and sexual interests are your own business. That information has value. If anybody wants to pay for an intimate look inside your life, let them make you an offer and you'll think about it." (William Safire, "Nosy Parker Lives," New York Times, Sept. 23, 1999, at A29.)

These new enactments do exactly that. The data protection directive, for example, conditions the collection, storage, use, or transfer of personal data on providing affected individuals with notice, obtaining their consent, providing them with access and an opportunity to correct disputed data, registering with national data protection authorities, and complying with other procedural and substantive requirements. U.S. laws, while imposing fewer restrictions on data processing, are moving in this direction, and are being vigorously, aggressively enforced.

"The difficulty," as Professor Eugene Volokh has written, "is that the right to information privacy-my right to control your communication of personally 
identifiable information about me-is a right to have the government stop you from speaking about me." (Eugene Volokh, "Freedom of Speech and Information Privacy: The Troubling Implications of a Right to Stop People From Speaking About You," 52 Stanford Law Review 1049, 105051,2000 .) Expanding the realm of information over which the law allows individuals to exercise control-without regard for harm - threatens the availability of information that is critical to expression.

Moreover, the debate over these laws has largely ignored their impact on expression. In the United States, rather than striking down laws like these that threaten access to, and communication of, information, the Supreme Court has endorsed them as legitimate economic regulation. In an unanimous opinion upholding the Drivers Privacy Protection Act, the Court wrote that "the personal, identifying information that the [law] regulates is a 'thing in interstate commerce," " and referred to that information throughout its opinion simply as "an article in interstate commerce," like a truckload of coal or steel. (Condon $v$ Reno, 528 U.S. 141, 148 (2000) (quoting United States v Lopez, 514 U.S. 549, 558-559 (1995)). This stands in stark contrast to the considerable protection that the Court has interpreted the First Amendment as applying to expression.

\section{THE NEED FOR BALANCE}

These developments in privacy and copyright law are troubling for at least four reasons.

First, they have very practical consequences for citizens' use of information to monitor public officials and the activities of our government. Without access to information and the freedom to express ourselves, citizens cannot elect their leaders and oversee the activities of the government. As James Madison wrote almost two centuries ago: "A popular Government, without popular information, or the means of acquiring it, is but a Prologue to a Farce or a Tragedy; or perhaps both. . . A people who mean to be their own Governors, must arm themselves with the power which knowledge gives." (James Madison, Letter to W.T. Barry, 4 August 1822, reprinted in 9 The Writing of James Madison 10 (Hunt ed. 1910)). The consent of the governed is the only legitimate source of sovereign power in a democracy, and it is only meaningful if informed.

A recent study by Professor Brooke Barnett found that U.S. journalists routinely use records, including those restricted by the Drivers Privacy Protection Act, not merely to check facts, but to actually identify the story in the first place. According to that study, 64 per cent of all crime-related stories, 57 per cent of all city or state stories, 56 per cent of all investigative stories, and 47 per cent of all political campaign stories rely on public records. Access to public record databases, Professor Barnett writes, is "a necessity for journalists to uncover wrongdoing and effectively cover crime, political stories and investigative pieces." (Brooke Barnett, "Use of Public Record Databases in Newspaper and Television Newsrooms," 53 Federal Communications Law Journal 557 (2001) (emphasis added).)

A 2001 High Court case suggests the impediment that the expansion of copyright and privacy law can pose to informing the public. When the Sunday Telegraph published a confidential minute recording a meeting between Tony Blair, Paddy Ashdown, and others at 10 Downing Street, Ashdown sued, claiming not that the minute was inaccurate or defamatory, but rather that its publication violated his copyright as its author. The High Court agreed, rejecting the Sunday Telegraph's claim that the publication was immunized by the protections for expression in the 1998 Human Rights Act. (Ashdown v Telegraph Group Ltd. [2001] EWCA Civ 1142 (18 July 2001)).

Second, the expansion of copyright and privacy law interferes with valuable commercial uses of information. Open information flows facilitate what courts have called a "marketplace of ideas." (Red Lion Broadcasting Co. v FCC, 395 U.S. 367, 390 (1969)). The marketplace is more than a metaphor: markets depend on information flows. Economists have long regarded access to information as one of the requirements of a competitive market, and the practical absence of such information as an inefficiency.

Allowing individuals to exercise control over information, in the absence of any specific threat of harm, has economic consequences, because data are used extensively in the market. Ubiquitous credit reports in the United States, for example, mean that Americans are judged based on their own credit history and qualifications, not stereotypes based on where they live, how old they are, or the color of their skin.

Those records have literally transformed the financial services sector. Banks, credit card issuers, insurers, and others make more services available to more people, on a more equitable basis, and at lower cost than ever before. A 2000 World Bank study showed that restrictive privacy laws would eliminate 11 out of every 100 people who currently qualify for mortgages, credit cards, and other loans. (John M. Barron \& Michael Staten, The Value of Comprehensive Credit Reports: Lessons from the U.S. Experience (2000))

Accessible credit records increase the speed with which credit decisions are made. In 1997, 82 per cent of automobile loan applicants received a decision within an hour; 48 per cent of applicants received a decision within 30 minutes. Many retailers open new charge accounts for customers at the point of sale in less than two minutes. The greater accuracy, speed, and efficiency of the credit 
system, and the greater confidence of lenders, also drives down the cost of credit-by an estimated $\$ 80$ billion per year for U.S. mortgages alone. (Walter F. Kitchenman, U.S. Credit Reporting: Perceived Benefits Outweigh Privacy Concerns 7 (The Tower Group 1999)).

These benefits derive from the fact that information is obtained routinely, over time, without consumers having control over the information. Allowing the consumer to block the collection or use of unfavorable information would make the credit report and other public and commercial records useless. As Federal Trade Commission Timothy Muris has noted: "If consent were required, and consumers could decide-on a creditor-by-creditor basis - whether they wanted their information reported, the system would collapse." (Timothy J. Muris, Protecting Consumers' Privacy: 2002 and Beyond, Privacy 2001 Conference, Cleveland, OH, 4 October 2001).

Open access to personal information is also critical to competition, by helping to level the playing field for new market entrants. Laws designed to protect privacy, Robert E. Litan, Director of the Economic Studies Program and Vice President of the Brookings Institution, has written, "raise barriers to entry by smaller, and often more innovative, firms and organizations." (Robert E. Litan, Balancing Costs and Benefits of New Privacy Mandates, Working Paper 99-3, AEI-Brookings Joint Center for Regulatory Studies (1999).)

A third reason to care about the impact of granting property-like rights in information is that those rights interfere with other beneficial uses of information, such as to foster individual development and self-fulfillment, further creativity and innovation, advance science, and promote social evolution.

Many of those benefits transcend either political or economic considerations. For example, the development of new medical treatments and drugs depends on the widespread availability of information. Helena Gail Rubenstein has written that "Privacy, which is intertwined with the concept of control over what is disseminated about oneself, is an expression of autonomy. ... [W]hile autonomy is an appropriate framework for evaluating questions concerning the treatment of one's body, it is not the appropriate framework for evaluating rules to regulate the use of health data." (Helena Gail Rubinstein, "If I am Only for Myself, What Am I? A Communitarian Look at the Privacy Stalemate," 25 American Journal of Law and Medicine 203, 226 (1999)). Rubenstein concludes: "As individuals rely on their right to be let alone, they shift the burden for providing the data needed to advance medical and health policy information. Their individualist vision threatens the entire community." (Id. at 226.)

Law enforcements' efforts to identify and bring to justice the terrorists who attacked the Pentagon and World
Trade Center, and to protect against future attacks, also demonstrate vividly the value of information. In the days after the terrorist attacks, officials sought information on suspects and their accomplices from hundreds of sources, including credit card companies, banks, airlines, rental car agencies, flight training schools, and thousands of private individuals. It rapidly became clear that personal information collected by the private sector was a significant resource in the campaign to track down the perpetrators and prevent future attacks.

Finally, these recent developments in copyright and privacy law warrant thoughtful debate precisely because they pose a largely invisible and therefore insidious threat to expression. Unlike direct attacks on expression, which courts have almost uniformly repelled, efforts to create ownership and control of information are far more subtle. Motivated by changes in markets and technologies, and especially the growth in the information services economy, these efforts to commodify data, and thereby restrict their use, are rarely even seen as a threat to traditionally protected expression interests. So few constitutional or foundational objections have been raised, and courts are only occasionally sympathetic when they are.

It is ironic that these developments in copyright and privacy law reflect almost opposite objectives. Businesses have lobbied Parliament and Congress and litigated aggressively to expand the monopoly granted them by copyright law and thereby exact greater compensation from individuals who wish to use copyrighted works and the information they contain. Recent privacy laws, by contrast, reflect an effort to give individuals greater control of the information about them that businesses wish to collect and use. Both efforts, however, have the effect of creating property-like rights in information that threaten to choke critical information flows.

Recognizing that threat does not necessarily mean that laws creating greater control over information are universally undesirable or should always be repudiated. Rather, it sets the stage for balancing laws that restrict information flows with the legitimate need for, and legal protection of, those flows. Where the former are necessary to respond to sufficiently significant harms or generate sufficiently great benefits, the latter may have to give way. But we should reach that conclusion explicitly, carefully, and reluctantly.

\section{Fred H. Cate}

Professor of law and Ira C. Batman Faculty Fellow at the Indiana University School of Law; - Bloomington; Senior policy advisor to the Hunton \& Williams Center for Information Policy Leadership; Visiting scholar at the American Enterprise Institute. 